\title{
The Implications of Cognitive Neuroscience in Optimizing the Balance Function of Right and Left Brain Through Learning on the Introduction to Accounting 1 Courses
}

\author{
Dessi Susanti \\ Economic Education Departement \\ Faculty of Economics \\ Universitas Negeri Padang \\ Email: mazaya@fe.unp.ac.id
}

\author{
Menik Kurnia Siwi \\ Economic Education Departement \\ Faculty of Economics \\ Universitas Negeri Padang \\ Email: menikkurnia@gmail.com
}

\begin{abstract}
This research examines the differences in cognitive value of students that taught on Introduction to Accounting 1 courses using Brain-based Learning model and Expositorybased Learning Model. The purposes of this study are to analyze (1) the differences on cognitive value of the students in Introduction to Accounting courses using Brain-based Learning model compared to Expository Learning Model; (2) The difference on cognitive value of students in Introduction to Accounting 1 courses with initial high and low motivation taught by Brain-based Learning models compared with the cognitive value of students with Expository Learning Model; (3) Interaction between Brain-based Learning model with motivation against cognitive value in Introduction to Accounting student. This type of research is quasi experiment. The populations are students taking the Introduction to Accounting course from July to December 2015 using purposive sampling technique. Experimental class taught using Brain-based Learning model while control class using Expository-learning model. Data analysis used 2-tailed ANOVA. The results of this research indicate that cognitive value of students in Introduction accounting 1 taught using Brain -based Learning model is higher than the cognitive value of students taught using Expository Learning model; and cognitive value of students in Introduction accounting 1 with high motivation taught by Brain-based Learning models more higher too; but cognitive value of students in Introduction accounting 1 with low motivation taught by Brain-based Learning models is lower than the cognitive value of students taught by Expository Learning model; so its conclude that there is any interaction between the Brain-based Learning model with motivation against cognitive value in Introduction Accounting 1 student.
\end{abstract}

Keywords-Brain-based Learning Model, Expository Learning Model

\section{INTRODUCTION}

Implications of cognitive neuroscience in education is the emergence of today's paradigm to new learning called the Brain Based Learning (BBL) is managing learning based on ability of the brain that involve full learners, where the learning pattern changed from relaxed into a pattern of active learning so that each node in the brain can play their respective roles in their entirety.

The learning model is believed by many parties directly have the role to enrichment process of the brain. Because the brain is better and should be enriched with new experiences that can stimulate growth and development of brain cells. It's believed that the brain had growth new cells every 20 minutes. [1]

The education process is important in human life, and learning activities there involving approaches and models of teaching and learning is one of the basic elements of the educational process. To that must be planned in a systematic and applicable. When it comes to learning, it is inseparable from the role and function of teaching. Quality learning can be realized when teachers have a some of competencies. In short learning process is the ability of teachers to empower all elements that can influence changes in learner behavior.

In fact, learners have a learning experience that is not always fun and interesting. Many of the complaints, among other material is boring, dry, and learning just behind the counter, rigid, monotonous and very formal. It based of attitude and low learning outcomes. How to design an interesting learning? It deals with the approach or learning strategies. If at this time the learners more use of the left hemisphere, what would happen if they use both hemispheres at once? Theoretically learners will have the brain power that is double, because taking its all capacity.

In 1950, professor of psychology at California Institute of Technology, Roger Sperry discovered that the brain is divided into two hemispheres, the right hemisphere and the left hemisphere. Each hemisphere of the brain has specialized in certain abilities, although there are several Crosses and interaction between the two hemispheres. The process of thinking left brain is logical, sequential, linear, and rational. This side is very organized. Although it is based on reality, it was able to interpret the abstract and symbolic. The way of thinks suitable for regular tasks, verbal expression, writing, reading, auditory association, put the details and facts, phonetic, and symbolism. Right brain thinking is random, irregular, intuitive and holistic. The way of think accordance 
with a way to know who is nonverbal, such as feelings and emotions, awareness with regard to the feeling (feel the presence of an object or person), spatial awareness, shape and pattern recognition, music, art, color sensitivity, creativity and visualization. Both parts of the brain important to be optimized, so that the balance between the functions of the right hemisphere of the brain and other parts[2].

Maximizing function left brain and right brain in learning to be very important. That is, not only emphasizes the ability of the left brain, but also develop the ability of the right brain. Empower the right brain in the learning process needs to be done and be intensified. Empowerment right brain is very important in building intelligence learner. Learners who are intellectually and emotionally intelligent have greater opportunities to achieve success in school. Therefore, for the educational process in schools can be successful, then education must refer to both hemispheres of learning in a balanced and comprehensive, one model of learning that maximize the function of the left brain and the right brain is called a model Brain Based Learning.

Faculty of Economics, according to its vision Being a faculty competitiveness in developing education and science in economics and business and its mission to organize higher education vocational, academic and professional in the field of economics and business to form the man who devoted, ethical, qualified, creative, innovative and globally competitive. To achieve the vision and mission is certainly not an easy matter, its demanded hard work and diligence of all parties, including teachers and students. In order to produce intelligent students intellectually and emotionally so that greater success in obtaining it requires education process refers to learning both hemispheres of the brain are balanced and thorough education process by using model Brain Based Learning answer the challenge.

The learning process for the subjects that are characterized mathematically logical student has not gained experience with approaches and models of learning: innovative, creative, fun, raise the motivation to learn, and create a relaxed learning, as a result they tend paradigm that the course is boring, dry, and learning just behind the counter, rigid, monotonous and very formal, and ultimately it result in low motivation and their learning outcomes.

Based on the above background it is essential were studying with Model Brain Based Learning as an innovative and creative model that aims to produce students who are intellectually and emotionally intelligent thus greater in obtaining success realized by the high motivation and their learning outcomes.

An alternative model of learning that can improve student-learning outcomes and create pleasant learning conditions, without a load, and the active involvement of students. BBL is a learning that is aligned with the way the brain that are designed by nature to learn, so that students actively to build a knowledge based cognitive structure which has been owned and based on the way the brain works so hopefully learning can be absorbed by the brain to the fullest. [8] States that if every teacher and administrator education institutions are able to use the BBL, it will fundamentally change the teaching activities, not only to be very effective, in fact almost the entire potential of a person to be awakened. [3] Brain based teaching and learning takes a holistic approach, looking at teaching developmentally, sociocultural, and in other broad ways. Brain based learning stresses the importance of patterning, that is, the fact that the brain does not easily learn things that are not logical or have no meaning. Because our natural tendency is to integrate information, we resist learning isolated bits of information. Because the specifics of instruction are always tied to larger understandings and purposes.

Characteristic of $\mathrm{BBL}$ is a learning relaxed classroom, constructivist learning, emphasizes the aspects of cooperation between students, there is sufficient time for students to reflect on the material that has been received, meaningful and contextual learning. The learning process using the BBL tends to be full of excitement, so that students are self-motivated. It encourages the brain's ability to integrate a number of comprehensive information as well as involving students in a learning process simultaneously involves the intellect, creativity, and psychology. [4] Brain based learning is a way of thinking about the learning process, it is not a panacea, nor is it the solution to all of our problems, it is not a program, dogma, or recipe for teachers. And it is not a trend or gimmick. It is, however, a set of principles and a base of knowledge and skills upon which we can make better decisions about the learning process.

BBL model is closely related to the brain's potential and readiness to empower students in the learning process. [5] Revealed that the readiness of students needs to be considered in the process of learning, because if students learn and there is readiness, the study results will be better. BBL has several stages, namely the pre-exposure, preparation, initiation and acquisition, elaboration, incubation and memory entry, verification and checking of beliefs, and stage celebrations. BBL treatment in the model so that students gain the maximum learning results in accordance with the capabilities. [6]

BBL Model contains seven syntax are all accommodated in this study. Learning to apply the BBL model can enable students to get better result and make students happier in the following study. Treatment in the BBL that a student can gain maximum learning results in accordance with capabilities.

The first syntax is pre-exposure, provide a brief review of the new learning before actually dig further. Preexposure helps students to build a better conceptual map. The more background possessed by students regarding the subject of learning, the sooner their proximity to absorb and process new information. This phase lecturer outlining the material to be studied, so that students can determine what the target material to be learned. The second syntax that preparation is the stage for lecturers to create curiosity or excitement. This stage in a video slide show of by lecturers, and students seek out the message that slides. Students are expected to be motivated and getting ready to do the learning. States that a 
student's readiness to consider in the process of learning, because if students learn and there is readiness, the study results will be better.

The third stage is the initiation and acquisitions; the stage provides full immersion learning charge, one of them by giving the facts start full of ideas, details, complexity, and meaning. Lecturer divides students into small groups and distributes the modules of each group. Lecturer raises accounting issues that occur in the community through articles that require students to think critically and scientifically act in response to the problems in the community.

The fourth stage is elaboration. This stage requires the ability to think purely of students, making learning becomes meaningful. This phase provides the opportunity for students to sort, search, analyze, test, and deepen learning. The activities at this stage are students doing practical activities of accounting, the Recording and analyzing articles. This happens because through trial activities students are given the opportunity to satisfy the urge of curiosity and want to be. This phase provides the opportunity for students to sort, search, analyze, test, and deepen learning independently. This is in accordance with the theory of constructivism, so that students can make sense of the concept itself is constructed so that the understanding of students increased. The advantages of this phase are to learn students to review and evaluate the work itself and friend, and can provide constructive feedback in a productive way. Elaboration process is the stage that ensures students will not just repeat the information from the facts, but also be able to connect the subject matter in a meaningful way. Each stage of the BBL to make learning more meaningful accordance David Ausubel meaningful learning theory. Meaningful learning is a process where new information on relevant concepts contained in a person's cognitive structure. [7]

The fifth syntax is incubation and inserts the memory. This phase emphasizes the importance of rest time and repeats. The brain learns most effectively over time and not directly at any one time. This phase the students reflect on learning through journal writing. Students write down the points of material they have not understood the learning material at a meeting that day, namely accounting and cycle. Phase insert the memory is designed in the form of games (games) before the study ended. [8] States that the elements of affective, cognitive, psychomotor and intellectual support can be enabled through the games, because the game is a means of learning the most effective and enjoyable. Playing method can make students more aware about what they learned and make the atmosphere more pleasant [10].

Stages of the six that verification and checking of confidence. This phase learners also need to confirm their learning for themselves. Confirmation is not only done with the presentation alone, but may also use other methods like mind map method. Mind maps are used in learning a positive impact on students. This caused a mind map to help develop thinking skills as well as improve memory because the information compiled branched off from the main theme with a picture, a combination of colors, symbols, shapes. Mind map is a technique overall utilization of the brain by using visual images and other graphics infrastructure to form an impression. This technique impact on the students to be feeling happy and brain functioning optimally, so that the learning can arouse interest, meaning, understanding of materials, and bring the values of the happy. [10] Confirmation is done by the students and then verified by the faculty to support the student knowledge and correct the errors of meaning built by students, as well as debriefing activities are also conducted by lecturers with the aim to allow students to express what is less understood so that it can be explained again by the lecturer.

Ekspository Learning Model is a model for the delivery of the subject matter there in include a mix of lectures, question and answer method, and the method of task. [11]

Review research :

Adrianna C Jenkins, Lusha Zhu and Ming Hsu : Cognitive neuroscience of honesty and deception: a signaling framework : has concluded that : Moreover, any realistic account of honesty and deception in humans must be able to account for the fact that information sharing is dominated by unstructured com-munication involving natural language and a diverse collection of nonverbal cues. However, no study to our knowledge has studied the neural mechanisms of honesty and deception in the context of unstructured communi- cation. In behavioral studies, unstructured communica- tion was found to substantially increased truth-telling and cooperation compared to structured communication where messages were preselected by the experimenters. Although intuitive, none of our existing theories are able to explain why this is so, and what specific features of unstructured communication are responsible for the ob-served differences. Advances in this area will likely require additional consideration of the contribution of language processes, for example by incorporating game theoretic models of pragmatics recently developed in linguistics

[2] attentionSantiago Morales, Xiaoxue Fu, Koraly E. PérezEdgar : A developmental neuroscience perspective on affectbiased attention : has concluded that : This review suggests that we should consider several factorswhen examining affectbiased attention and its relation to socioe-motional functioning: 1) Affect-biased attention is not a singleconstruct, but arises from the interaction of multiple attentionalsystems. 2) Affect-biased attention and its role in socioemotional functioning might change over the course of development as sub-components of attention emerge and strengthen, and are coupledwith experience. 3) Affect-biased attention is not limited to atten-tion bias towards threat and anxiety-related outcomes. Rather,it is a domain-general mechanism that shapes the type of infor-mation an individual has available when characterizing, actingon, and responding to the environment. 4) The relation between affect-biased attention and socioemotional functioning seems tobe reciprocal rather than unidirectional.

Brandon M. Turner, Birte U. Forstmann, Bradley C. Love, Thomas J. Palmeri: Approaches to analysis in modelbased cognitive neuroscience: has concluded that: The field of 
cognitive science has only begun to realize the full potential of combining brain and behavior as a way to study the mind. However, the field relies on the various approaches developed By different groups of methodological experts. Due to the seemingly disjoint ways to study cognition, many neuroscientists and cognitive modelers are unaware of their modeling options, as well as the benefits and limitations of different approaches. In this article, we have described the currently prominent general methods for integrating neural and behavioral measures, while providing some examples of their use in cognitive neuroscience. We then attempted to organize these approaches on the basis of a variety of factors: the number of stages, the commitment to a particular B.M. theory, the type of information flow, the difficulty of implementation, and the type of exploration. We concluded with a discussion of limitations and further considerations in approaching the integration problem. Our comparison of the approaches. that a broad spectrum of methods exists for performing model-based cognitive neuroscience, and there are Important considerations and limitations of each approach. In the end, we conclude that model-based approaches in cognitive neuroscience are extremely important, and the choice of analysis strongly depends on the research goal. It seems to us that having a clearly articulated analytic goal in mind serves as the impetus for successful integration between neuroscientific measures and cognitive theory.

Manuel Martín-Loeches : Neuroscience and education: We already reached the tipping point: has concluded that: show how the adolescent's brain is, in this regard and in the words of Sebastian, a 'fast car with poor brakes'. In conclusion, the contributions in this monograph - for which we are really thankful to all the authors - provide definite evidence on the relevance of neuroscience for educational and pedagogic matters, even in its current state. It is not necessary to wait any longer; there is already sufficient neuroscientific knowledge. The most exhilarating is, however, that the future of educational neuroscience appears highly fruitful and promising

[13] Tineke Broer, Martyn Pickersgill : Targeting brains, producing responsibilities: The use of neuroscience within British social policy : has concluded that: Our analysis thus indicates the import of neuroscience to UK social policies, whilst simultaneously suggesting caveats both for generalizing out from particular reports and policy domains, and for assuming that broader societal implications emerge from these. For one, the fact that neuroscientific terms and concepts exist within policy reports does not necessarily imply fundamentally new kinds of social praxis, given the correspondence of the leveraging of neuroscience in policy with the widespread deployment of psychological knowledge in the twentieth century (even if ontologies of self and society are themselves partly recast within policy documents). Further, our findings demonstrate why it remains important to be mindful both of the limits to which a neurobiological idiom is deployed in policy settings (and elsewhere), and of the extent to which critical discourses may proliferate even within the terrain where the terms and concepts of the neurosciences occupy space. . In so doing, sociological studies can contribute to increased empirical specificity concerning the salience of neuroscientific knowledge whilst refusing to reproduce any notion that the neurosciences have a uniformly dominant role (to play) in contemporary policy and everyday life.

Brandon M. Turner, Birte U. Forstmann, Bradley C. Love, Thomas J. Palmeri, Leendert Van Maanen : Approaches to analysis in model-based cognitive neuroscience : has conclude that : The field of cognitive science has only begun to realize the full potential of combining brain and behavior as a way to study the mind. However, the field relies on the various approaches developed by different groups of methodological experts. Due to the seemingly disjoint ways to study cognition, many neuroscientists and cognitive modelers are unaware of their modeling options, as well as the benefits and limitations of different approaches. In this article, we have described the currently prominent general methods for integrating neural and behavioral measures, while providing some examples of their use in cognitive neuroscience. We then attempted to organize these approaches on the basis of a variety of factors: the number of stages, the commitment to a particular theory, the type of information flow, the difficulty of implementation, and the type of exploration. We concluded with a discussion of limitations and further considerations in approaching the integration problem. Our comparison of the approaches. That a broad spectrum of methods exists for performing model-based cognitive neuroscience, and there are Important considerations and limitations of each approach. In the end, we conclude that model-based approaches in cognitive neuroscience are extremely important and the choice of analysis strongly depends on the research goal. It seems to us that having a clearly articulated analytic goal in mind serves as the impetus for successful integration between neuroscientific measures and cognitive theory.

\section{RESEARCH METHODOLOGY}

The type of This research is a quasi experimental study that provided the treatment in the experimental group and compared with a control group by giving different treatment. Class experiments were treated in the form of learning with models Brain Based Learning, while the control class with Ekspository learning models.

The population in this study were students who took a course Introduction to Accounting 1 semester from July to December 2015. The sample was student on the introductory accounting 1, the fisrt class with section code 201510530021 as a control class and the second class with section code 201510530020 as a experimental classes. Students devided into groups top (high motivation) and a lower group (low motivation) according Arikunto is to take over the $27 \%$ top group and $27 \%$ lower group. Top group (high motivation) is based on $27 \%$ of the students who received grades of motivation. As for the lower group (low motivation) is $27 \%$ of the students who have low motivation. 


\section{RESEARCH RESULTS AND THEIR DISCUSSION}

A quasi-experimental design in this study using experimental design $2 \times 2$ factorial design was applied to two classes of students were assigned randomly. With the motivation of each student's learning and using different learning models, they studied the same subject in order to achieve the acquisition of learning in the form of cognitive maximum value. Thus, the motivation serve as a moderator variable, learning model used as the independent variable, and the value of cognitive serve as the dependent variable.

Tabulation of data owned student learning motivation can be seen in the table below.

TABLE I. Number of students based on learning motivation in the experimental class and control class.

\begin{tabular}{|l|l|l|}
\hline Model & High Motivation & Low Motivation \\
\hline BBL & 12 & 7 \\
\hline Ekspository & 9 & 7 \\
\hline
\end{tabular}

Based on the above table it can be seen that the students in the experimental class (BBL) amounted to 12 students have high motivation to learn, and 7 students have low learning motivation. As for the control class (Expository) students who have high motivation to learn amounted to 9 students, and students who have low learning motivation amounted to 7 students.

Value cognitive students measured using written tests conducted twice and questions used are the result of adoption of the book by Niswonger Warren titled Accounting Principles Volume I pages 160, 169 and 276. The data results showed that after completing a learning activity introductory accounting 1 in the second grade students earned grades of cognitive domains. Description of student cognitive value presented in the following table.

\section{TABLE II. DEPENDENT VARIABLE: COGNITIVE} VALUE

Descriptive Statistics

\begin{tabular}{|cc|r|r|r|}
\hline MOTIVATION & MODEL & \multicolumn{1}{|c|}{ Mean } & Std. Deviation & N \\
\hline LOW & BBL & 58.43 & 17.859 & 7 \\
& EKSPOSITORY & 63.71 & 27.275 & 7 \\
& Total & 61.07 & 22.318 & 14 \\
\hline HIGH & BBL & 80.42 & 14.267 & 12 \\
& EKSPOSITORY & 67.11 & 24.117 & 9 \\
& Total & 74.71 & 19.751 & 21 \\
\hline Total & BBL & 72.32 & 18.694 & 19 \\
& EKSPOSITORY & 65.62 & 24.714 & 16 \\
& Total & 69.26 & 21.585 & 35 \\
\hline
\end{tabular}

Result of testing the hyphothesis 1 is:

The cognitive value of Introduction to Accounting 1 students taught by the model Brain Based Learning is higher than the value of cognitive Introduction to Accounting 1 students taught using models Ekspository Learning. From the analysis of the data and test the hypothesis $\mathrm{H} 0$ and $\mathrm{H} 1$ accepted which means that the students are taught cognitive learning model
BBL has a higher value than the students who were taught using learning model ekspository. This is evident by looking at the ratio of the average value of the both class, students are taught the learning model BBL has an average value of 72.32 and students are taught with ekspoitory learning model has an average value of 65.62 . Based on these results it can be said that the learning model BBL generate better value for students. BBL learning model emphasizes on the ability of the brain to work optimally. Stimulus in the form of video, games and motivation and fun learning process make students relax during the study. Comfortable and pleasant situation is very helpful brain to work optimally. At the time of the brain in optimal conditions lecture material is given so that students can absorb properly, which in turn produces a high value anyway.

\section{Result of testing the hyphothesis $\mathbf{2}$ is:}

The cognitive value of Introduction to Accounting 1 students with high motivation taught by models Brain Based Learning is higher than the value of cognitive Introduction to Accounting 1 students with high motivation taught by models Ekspository Learning. From the analysis of the data and test the hypothesis $\mathrm{H} 0$ and $\mathrm{H} 1$ accepted which means the value of cognitive domains with highly motivated students who are taught by learning model BBL higher than the high motivation of students who were taught using learning model ekspository. This is evident by looking at the ratio of the average value of the both class, students are taught the learning model BBL has an average value of 80.42 and students are taught with ekspoitory learning model has an average value of 67.11. Students who have a high motivation to learn is to have the spirit of learning and teaching model BBL encouraging them to follow the entire lecture. Students who have high motivation tend to like new things and be creative so that more pleased if taught with instructional model that involves the activity of the students therein. While the learning model ekspository highly motivated students tend to get bored and reduce the spirit of learning so that its value becomes less than the maximum.

\section{Result of testing the hyphothesis 3 is:}

The cognitive value of Introduction to Accounting 1 students with low motivation taught by models Brain Based Learning is higher than the value of cognitive students with low motivation taught by models Ekspository Learning. From the analysis of the data and test the hypothesis $\mathrm{H} 0$ and $\mathrm{H} 1$ rejected, which means that the value of cognitive students with low motivation taught by BBL learning model is no higher than the low motivation of students who were taught using learning model ekspository. This is evident by looking at the ratio of the average value of the both class, students are taught the learning model BBL has an average value of 58.43 and students are taught with ekspoitory learning model has an average value of 63.71. Students with low learning motivation prefers taught learning model ekspository because they are lazy actively involved in learning. Although the BBL learning model presents many learning strategies that attract and excite 
but less influence on students with low motivation to not much improve learning outcomes.

\section{Result of testing the hyphothesis 4 is:}

There is an interaction between the model Brain Based Learning with motivation against cognitive value Introduction to Accounting 1 student. From the analysis there is interaction between the learning model and motivation (motivation * Model) by providing value F 1.682 and significant at 0.05 this means that there are significant joint or joint effect is different between each model of the value of learning and cognitive motivation of students. Brain Based Learning learning model with high motivation positive outcomes for students cognitive value, but the results are less if the interaction occurs on a learning model BBL with students who have a low learning motivation. While students with high motivation taught by learning model ekspository results less than the maximum, and vice versa if the low motivation of students taught by ekspository learning model provides better value. With so motivation is not always a positive influence on every model of applied learning. The learning model is creative and innovative and is supported by a high learning motivation will certainly produce a high value for students.

\section{CONCLUSION}

The process of learning in class is the process of transfer of knowledge and attitude for the cultivation of learners including students. The learning process does not always work well because many factors influence one of them is how lecturer teach or apply appropriate learning models to improve student grades.

Brain Based Learning is an alternative model of learning that can improve student learning outcomes and create a pleasant learning conditions, without a load, and the active involvement of students. BBL is a learning that is aligned with the way the brain that are designed by nature to learn, so that students actively to build a knowledge based cognitive structure which has been owned and based on the way the brain works so hopefully learning can be absorbed by the brain to thefullest.

Brain Based Learning model is better in improving the cognitive value of students as compared to students who were taught using model ekspository.

Motivation to learn the students divided into two high motivation and low motivation. The motivation of every student have different effects on their learning outcomes. The interaction between the learning motivations of high learning model BBL will increase the value of cognitive students. While students with low motivation would be better if taught using learning model expository.

\section{ACKNOWLEDGMENTS}

This is the original article on our results, and we say that we are responsible for the content of this article, and we stated that the article had never been to a conference or send it to another journal. Thanks are due to Rector of State
University of Padang, Prof. Ganefri have supported us to participate in this conference, Thank you.

\section{REFERENCES}

[1] Given, B. K. (2007). Brain-based Teaching. (L. H. Dharma, Penerj.) Bandung: Kaifa.

[2] Anwar Fuady, M.Ed., Drs. 2008. Paradigma Baru Dalam Pendidikan danPembelajaran Learning Is Fun.

[3] Caine RN, Caine G - Educationa Targeting Brains, Producing Responsibilities: The Use Of Neuroscience Within British Social Policy Leadership, 2002, Ebsco Publishing. Accessed on 19 September 2016

[4]

Jensen, E. (2008). Brain-Based Learning (Edisi Revisi). (N. Yusron, Penerj.) Yogyakarta: Pustaka Pelajar.

Slameto. (2010). Belajar dan Faktor-Faktor yang Mempengaruhinya. Jakarta: Rineka Cipta.

[6] Ardiasih, R. T. (2009). Eksperimen Pembelajaran Matematika melalui Brain Based Learning pada Pokok Bahasan Matriks ditinjau dari Keaktifan Siswa. Skripsi tidak dipublikasikan, FKIP UMS, Surakarta

[7] Dahar, R., W. (2011). Teori- teori Belajar dan Pembelajaran. Jakarta: Erlangga

[8] Ismail, A. (2006). Education Games menjadi Cerdas dan Ceria dengan Permainan Edukatif. Yogyakarta: Pilar Media.

[9] Saptawulan, A. (2012). Belajar Biologi yang Menyenangkan dengan Permainan Kuartet dan Pementapan Konsep secara Mandiri melalui Blog. Jurnal Pendidikan Penabur, 18, 28- 35.

[10] Budiman, P. (2008). Penerapan Teknik Peta Pikiran untuk Meningkatkan Pemahaman Siswa pada Mata Pelajaran Ilmu Pengetahuan Sosisal Kelas VC SD Santa Ursula BSD, Jurnal Psiko-Edukasi, 6: 34-51.

[11] Sunaryo. 1989. Strategi Belajar Mengajar Dalam Pengajaran Ilmu Pengetahuan Sosial. Jakarta: DEPDIKBUD

[12] Arikunto, Suharsimi. 2006. Penelitian Tindakan Kelas. Jakarta: Bumi Aksara.

[13] Broer Tineke \& Pickersgill Martyn. Targeting Brains, Producing Responsibilities: The Use Of Neuroscience Within British Social Policysocial Science \& Medicine 132 (2015) 54e61. Published by Elsevier Ltd. This is an open access article under the CC BY license. Accessed on 19 September 2016. 